\title{
Peranan Radio Republik Indonesia Yogyakarta Dalam Pelestarian Karawitan
}

\author{
KRISWANTO ${ }^{1}$ \\ Jurusan Karawitan, Fakultas Seni Pertunjukan, Institut Seni Indonesia Yogyakarta
}

\begin{abstract}
The Role of Indonesian Republic Radio of Yogyakarta in Preserving Karawitan. This article discusses the role of Indonesian Republic Radio (RRI) Yogyakarta in the preservation of karawitan. RRI Yogyakarta -born through MAVRO (1934) and Japan Radio Hosokyoku (1942), officially established on September 11, 1945- is a place for the existence of Uyon uyon Manasuka. Uyon-uyon Manasuka -originally known as Doyo Mardowo- becomes one of the prime shows in RRI Yogyakarta on the struggle of Ki Tjokrowasito who later became the boss. The characteristics of uyon-uyon Manasuka which were different from uyon uyon Hadiluhung Sultan Palace and Uyon uyon Muryoraras Pura Paku Alaman, enrich the cultural treasures of Yogyakarta. Since its birth until now, its existence still gets its own place for people of Yogyakarta. Even present society is still getting involved directly through interactive contacts. Besides uyon-uyon Manasuka, RRI Yogyakarta also facilitates the activities of community-uyon uyon packed in lunch-uyon uyon events
\end{abstract}

Key words: Uyon-uyon, karawitan, Indonesian Republic Radio

\section{Pendahuluan}

Sebelum Indonesia merdeka (1945), Radio Republik Indonesia (RRI.) Yogyakarta sebenarnya telah dikenal oleh masyarakat pribumi dengan sebutan MAVRO. Ketika itu, banyak organisasi radio yang hidup dan beroperasi di bawah pemerintahan penjajah Belanda, di antaranya adalah $S R V$ (Solo, 1933), VORO (Jakarta, 1934), VORL (Bandung, 1934), CIVRO (Surabaya, 1935), dan MAVRO (Yogyakarta, 1934). Di samping itu pemerintah Belanda sendiri memiliki organisasi radio bernama NIROM. Dalam operasionalnya, NIROM berkeinginan menguasai keberadaan radio-radio ketimuran (pribumi) untuk kepentingannya. Karena begitu kuatnya posisi radio-radio ketimuran yang telah tergabung dalam sebuah organisasi bernama P.P.R.K. (Perserikatan Perkumpulan Radio Ketimuran), niat tersebut tidak dapat terwujud (Suryo Sumarno, 1985: 18).

Sebagai anggota PPRK, MAVRO secara resmi mengudara pada tanggal 22 Februari 1934 dengan segala keterbatasan dalam menyelenggarakan siarannya. Setelah mendapat bantuan finansial dari Sri Sultan Hamengku Buwana VIII, barulah $M A V R O$ tampak semakin maju. Dalam menjalankan misinya, $M A V R O$ mengudara melalui dua studio di dua tempat berbeda yakni Kepatihan untuk siaran sore hari dan Dalem Ngabean untuk siaran malam hari. Mata acara yang menjadi menu pokok masyarakat saat itu adalah jenis hiburan. Kebebasan $M A V R O$ ini harus terhenti ketika Jepang menguasai Indonesia (1942) sehingga kedudukannya sempat berada di bawah kendali Radio Jepang Hosokyoku. Walaupun demikian, semangat yang mendasari jiwa para angkasawan menjadikan motivasi untuk dapat lepas dari kendali Jepang. Hal ini dibuktikannya ketika Jepang menyerah kalah pada sekutu tahun 1945, para angkasawan benar-benar memanfaatkan kesempatan ini untuk merebut Radio Jepang Hosokyoku. Melalui perundingan singkat akhirnya disepakati bahwa Radio Jepang Hosokyoku boleh diganti namanya menjadi Radio Republik Indonesia pada 11 September 1945. Sejak terbentuknya lembaga ini, RRI Yogyakarta telah mengalami berbagai cobaan yang begitu berat. Namun berkat semangat dan perjuangan yang gigih dari para angkasawan,

1 Alamat Korespondensi: Prodi Karawitan ISI Yogyakarta, Jln. Parangtritis Km. 6,5 Sewon, Yogyakarta, Tlp. 0274375380, HP: 081904010293. 
RRI Yogyakarta telah mampu menemukan jati dirinya melalui kemasan acara-acara menarik dan khas yang terbukti mampu mengundang simpati para pendengar sehingga keinginan selalu dekat dengan rakyat dapat terwujud. Adapun status Nusantara II yang dimiliki oleh RRI Yogyakarta baru diberlakukan pada tahun 1953 (Siswadi, 1985: 12-25).

Pada masa pemerintahan orde baru, RRI Yogyakarta berstatus (strata) Nusantara II dan bernaung di bawah Departemen Penerangan dengan sebutan RRI. Stasiun Nusantara II Yogyakarta. Tahun 2000 hingga sekarang (era reformasi) sebutan tersebut berubah menjadi RRI. Cabang Madya Yogyakarta dengan status kelembagaan Perja (Perusahaan Jawatan) yang bernaung di bawah Departemen Keuangan. RRI Yogyakarta merupakan satu lembaga komunikasi masa elektronik auditif yang berfungsi sebagai sarana komunikasi timbal balik antara pemerintah dan masyarakat. Sebagai radio milik pemerintah, sudah barang tentu keberadaannya tidak dapat terlepaskan dengan NKRI (Negara Kesatuan Republik Indonesia). Dalam operasionalnya, RRI Yogyakarta berperan sebagai corong pemerintah dalam menyebarluaskan berbagai informasi, di antaranya adalah pesan-pesan pembangunan, pemberitaan, hiburan, dan sebagainya (Paku Alam VIII, 1985: 14-15).

Di samping berfungsi sebagai sarana informasi mutakhir, RRI Yogyakarta juga pernah menyiarkan hiburan-hiburan segar yang mampu merebut hati para penggemarnya, antara lain adalah musik pop, wayang orang, wayang kulit, ketoprak, pembacaan puisi dan sebagainya (Amin Rais, 1985: 37-41). Acara-acara lain yang juga banyak digemari oleh masyarakat adalah Sandiwara Radio berbahasa Jawa, Butir-butir Pasir di Laut, Mbangun Desa (Ida Bagus Mantra, dalam Suryo Sumarno, 1985: 42-47), Ketoprak Mataram dan uyon-uyon, siaran karawitan khususnya Uyon-uyon Manasuka (Suryo Sumarno, 1985: 62-63).

\section{Uyon-Uyon Manasuka}

Sejak RRI Yogyakarta masih berbentuk embrio (Mavro), telah banyak perkumpulan karawitan yang ikut mengisi siaran, antara lain Lelangen Karawitan dari Keraton Yogyakarta. Dari luar keraton terdapat sejumlah perkumpulan, yaitu Daya Pradhangga, Laras Madya, Nindya Yatmaka, dan masih banyak perkumpulan-perkumpulan lain pada masa Pemerintahan Sri Sultan Hamengku Buwana VIII. Pada pasca kemerdekaan (tahun 1947-an), atas ide R.M. Soemarmadi dibentuklah satu perkumpulan karawitan inti yang anggotanya berjumlah 15 orang, terdiri atas tiga kelompok karawitan ternama waktu itu, yakni Keraton, Kepatihan, dan Pura Paku Alaman. Perkumpulan tersebut kemudian diberi nama Doyo Mardowo di bawah pimpinan Ki Tjokrowasito yang selanjutnya menjadi pembantu tetap RRI. dalam menyelenggarakan siaran uyonuyon (Suryosumarno, 1085: 63). Penyelenggaraan uyon-uyon itu sendiri berlangsung pada setiap hari Senin pukul 21.00 sampai dengan 00.30 yang mendapatkan sambutan meriah dari masyarakat pendengar. Istilah manasuka waktu itu belum dikenal luas, setelah siaran uyon-uyon berlangsung beberapa kali, barulah timbul gagasan untuk menampilkan siaran yang variatif. Para seniman yang tergabung dalam Doyo Mardowo itu kemudian mengadakan diskusi untuk membahas dan menentukan bentuk tampilan baru. Dengan pertimbangan dan dasar dari para pandhemen yang begitu banyak, maka terlontarlah sebuah ide manasuka (siapa senang), sehingga nama Doyo Mardowo berubah menjadi manasuka, kemudian berkembang menjadi Uyon-uyon Manasuka. Melalui format baru ini masyarakat diberi kesempatan untuk dapat terlibat dalam acara ini dengan cara menyampaikan permintaan terhadap gendinggending yang akan disiarkan melalui kartu Pilpen (pilihan pendengar) khusus yang berlabel Uyonuyon Manasuka. Satu kenyataan bahwa setiap kali siaran, kartu yang masuk di meja penyiar rata-rata mencapai 250 lembar, sebuah angka yang cukup banyak untuk ukuran waktu itu.

Gending-gending yang senantiasa menjadi langganan permintaan para pandhemen dalam acara Uyon-uyon Manasuka ini antara lain Ladrang Pangkur Laras Slendro Patet Sanga, Gending Bondet Laras Slendro dan Pelog, Gending Gambir Sawit Laras Slendro Patet Sanga, dan masih banyak lagi gending-gending lainnya. Adapun tokoh-tokoh karawitan di RRI Yogyakarta yang ikut memperkuat keberadaan Uyon-uyon Manasuka sekaligus menjadi idola pendengar adalah Niken Larasati, Riyo Larasati, Mursinah, dan Maria Magdalena Rubinem, keempatnya adalah sebagai waranggana/swarawati. Tokoh seniman kenamaan yang berperan di antaranya 
adalah Ki Tjokrowasito, Mas Bei Lebda Bremara (Ki M. Mujiono), Ki Sudarto, Lurah Lokasari, Lurah Gonjang Anom, Ki Prodjo Sastro Atmodjo (Amat Jali), Ki Sudarsono.

Dalam format baru tersebut terasa sekali bahwa kemasan Uyon-uyon Manasuka memiliki nuansa yang khas, yaitu setiap menjelang akhir pergelaran selalu ditampilkan sajian Pangkur Jenggleng. Pangkur Jenggleng adalah sebuah sajian bersifat guyon maton yang dikemas secara komunikatif melalui perpaduan antara gamelan, vokal, lawak, dan dialog bebas dengan mengambil tema tentang situasi dan kondisi sosial yang sedang berkembang saat itu. Sesuai dengan namanya, gending yang disajikan adalah Ladrang Pangkur Laras Slendro Patet Sanga yang digarap secara khusus dengan menampilkan banyak tabuhan genjlengan dan suara vokal serta dialog yang dilakukan sahut menyahut sehingga berkesan riang. Pangkur Jenggleng dapat pula disajikan dalam laras pelog patet barang dan laras slendro patet manyura.

Hadirnya Pangkur Jenggleng ini ternyata lebih menambah variasi sajian, karena di tengah-tengah acara ini selalu diselingi dengan pesan-pesan pembangunan, kritik-kritik sosial yang semua itu dikemas melalui lawakan dan banyolanbanyolan segar, sehingga tidak membosankan bagi pendengar. Terlebih yang memerankan lawakan ini adalah tokoh kenamaan saat itu, yakni Basiyo dan kawan-kawan. Pada kurun waktu 1960 hingga 1975 Uyon-uyon Manasuka pernah menjadi acara favorit bagi kalangan tua tidak hanya di pelosok wilayah Daerah Istimewa Yogyakarta, melainkan juga di Jawa Tengah dan sekitarnya. RRI Yogyakarta merasa kehilangan salah satu tokoh seniman lawak setelah Basiyo meninggal dunia karena serangan jantung pada 31 Agustus 1979, namun kelangsungan Uyon-uyon Manasuka tetap terjaga dengan baik dan bertahan hingga sekarang melalui penampilan tokoh lawak generasi berikutnya, yaitu Ngabdul, Poniman, Yuningsih 'mBok Beruk', dan Waluh sebagai generasi penerus Basiyo dan kawan-kawan.

Sejalan dengan kemajuan teknologi dewasa ini, RRI Yogyakarta telah mengadakan inovasiinovasi dalam menyiarkan Uyon-uyon Manasuka, di antaranya adalah mengadakan siaran luar yang dilakukan secara langsung, mengadakan kontak interaktif melalui telepon dan short massage system (sms) dengan para pandhemen, dan yang lebih memasyarakat lagi bersedia memenuhi panggilan siaran luar, baik bersifat pribadi maupun kelembagaan. Sebagai contoh, sudah tiga kali dalam tiga tahun terakhir ini Uyon-uyon Manasuka mengadakan siaran langsung di Pendopo Jurusan Karawitan-Pedalangan dalam rangka ikut memeriahkan Dies Natalis ISI Yogyakarta. Dewasa ini personil yang mendukung Uyon-uyon Manasuka didomonasi generasi muda dengan kualifikasi pendidikan minimal setingkat Sekolah Menengah Umum, karena anggota dari kalangan generasi tua telah banyak yang purna tugas, bahkan $\mathrm{Ki}$ Utarakandha (pengendang) telah meninggal dunia.

\section{Uyon-uyon Manasuka dari Masa ke Masa}

Penyajian (garap) Uyon-uyon Manasuka memiliki gaya yang khas dalam arti bukan sepenuhnya dibawakan dalam gayaSurakarta namunbukan pula gaya Yogyakarta secara utuh. Menurut pengamatan R. Wiranto, penyajian Uyon-uyon Manasuka itu pada dasarnya adalah dibawakan dalam gaya Yogyakarta yang telah dibesut atau diperhalus, di samping juga dipengaruhi oleh perangkat gamelan yang mendukungnya. Gamelan yang dipakai untuk Uyon-uyon Manasuka adalah bergaya Yogyakarta dan memiliki embat berbeda dengan jenis gamelan gaya Surakarta.. Senada dengan R. Wiranto, Murwanto (Mas Wedana Murwawinata [pimpinan Uyon-uyon Manasuka saat sekarang]) mengatakan bahwa penggunaan jenis gamelan, laya, dan teknik tabuhan pada instrumen tertentu sangat mempengaruhi terhadap karakter gending yang disajikan. Dengan kata lain bahwa meskipun sajian Uyon-uyon Manasuka secara eksplisit bukan gaya Yogyakarta maupun Surakarta, namun perlu diingat bahwa: (1). Pada awal pembentukannya dilakukan oleh para seniman yang sebagian besar memiliki latar belakang kemampuan karawitan gaya Surakarta. Ki Tjokowasito (pimpinan Uyon-uyon Manasuka periode pertama) sendiri merupakan sosok seniman (juga pencipta gending) yang hidup dan dibesarkan di lingkungan Pura Paku Alaman. Dengan demikian buah pikirannya selalu memberikan inspirasi dalam penggarapan gending yang disajikan, sehingga tampak jelas bahwa aransemen gending-gendingnya cenderung bergaya Surakarta. (2). Jenis gending yang disajikan sebagian besar adalah gaya Surakarta, dengan demikian kedalaman alur lagu dan teknik 
garapnya lebih sesuai menggunakan pola gaya Surakarta.

Sejak kelahirannya hingga saat ini, Uyon-uyon Manasuka telah mengalami lima kali periode kepemimpinan; Ki Tjokrowasito, Ki M. Mujiono, Ki Suhardi (Alm.), Ki Sugiarto, dan Ki Murwanto.

\section{Periode Ki Tjokrowasito (1951-1976)}

Ki Tjokrowasito adalah tokoh seni yang namanya tidak asing di kalangan seniman, pemerhati seni, pandhemen seni terutama seni karawitan. Tjokrowasito yang bernama kecil Wasi Djaladara adalah sosok seniman dan pencipta gending yang berbakat dan mumpuni di bidang seni karawitan. Sejak kecil bakat kesenimanannya telah nampak, dan ini dikembangkan di Pura Paku Alaman melalui pengabdiannya sebagai abdi dalem niyaga. Kecakapan yang dimilikinya membuat Sri Paku Alam VII tertarik dan mengangkatnya menjadi pimpinan abdi dalem niyaga dengan pangkat Raden Ngabehi (R.Ng.). Sejumlah nama dan pangkat yang disandang oleh Tjokrowasito (R.Ng. Tjokrowasito, KRT. Wasitodipuro, KRT. Wasitodiningrat, dan terakhir K.P.H. Notoprojo) merupakan bukti nyata dan penghargaan yang dianugerahkan oleh Sri Paku Alam karena dedikasi dan loyalitasnya yang tinggi terhadap Pura.

Dalam kiprahnya memimpin Uyon-uyon Manasuka RRI Yogyakarta, Tjokrowasito sengaja meletakkan warna pondasi karawitan lain dari yang telah ada sebelumnya (gaya Yogyakarta dan gaya Surakarta). Hal ini bukanlah satu kebetulan, melainkan di balik semua itu ada misi tertentu yang ingin dicapainya yakni sebagai pengrawit dan seniman mumpuni dan ternama sebagaimana dilakukan oleh ayahnya, Padmowinangun di Pura. Sebagai pimpinan karawitan, ia memiliki tanggung jawab penuh untuk membuat dan menentukan garap gending yang akan disajikan. Apabila sajian yang ditampilkan mengacu pada gaya sebagaimana dilakukan di Pura Paku Alaman maupun Keraton Yogyakarta, diprediksi ketenaran Uyon-uyon Manasuka tidak akan melampaui keduanya. Prediksi ini muncul mengingat garap karawitan di Pura maupun Keraton telah ada pada posisi puncak yang mapan dan mendapatkan legitimasi penguasanya masing-masing. Terlebih seperangkat gamelan satu-satunya yang dimiliki RRI Yogyakarta (Kyai Sadad Pengasih dan Kyai Kuntul Wiranten) adalah bergaya Yogyakarta, sehingga sulit untuk memunculkan sajian dengan karakter prenes sebagaimana dimiliki karawitan gaya Surakarta, karena faktor embat yang berbeda. Pada tahun 1980-an, RRI Yogyakarta memiliki dua perangkat yang lain, yaitu Kanjeng Kyai Horeg Bumi (hadiah dari Menteri Penerangan R.I. Ali Murtopo saat itu) dan Kanjeng Kyai Ngujiwat. Keduanya bergaya Surakarta dan pernah dipakai untuk mendukung Uyon-uyon Manasuka, namun karena dipandang kurang sesuai dengan jiwa dan karakter Uyon-uyon Manasuka itu sendiri, maka penggunaan gamelan kembali pada Kanjeng Kyai Sadad Pengasih dan Kanjeng Kyai Kuntul Wiranten.

Semangat Tjokrowasito dalam mengembang kan karawitan memang tidak tanggung-tanggung. Para musisi di bawah kepemimpinannya yang saat itu (tahun 1960-an) mencapai tidak kurang dari 75 orang, di samping aktif mendukung terselenggaranya Uyon-uyon Manasuka juga mengadakan siaran karawitan dalam bentuk dan kemasan acara berbeda, baik secara langsung maupun rekaman. Masyarakat DIY dan sekitarnya, terutama di pelosok pedesaan yang memang haus akan hiburan boleh merasa puas dan terhibur karena hampir setiap hari dapat menikmati gending-gending Jawa yang disiarkan melalui RRI Yogyakarta. Adapun jadwal tetap siaran karawitan itu dapat dilihat dalam tabel 1 .

Menyimak begitu padatnya frekuensi siaran karawitan yang terjadi pada kurun waktu 19601970, menyebabkan kesenjangan/kecemburuan bagi acara-acara lain seperti musik pop, keroncong, dan jenis-jenis hiburan lainnya yang mendapatkan porsi siaran lebih sedikit. Dengan dasar itulah maka frekuensi siaran karawitan dikurangi, namun demikian acara siaran Uyon-uyon Manasuka tetap dipertahankan untuk tetap mengudara.

\section{Periode Ki Mujiono (1976-1985)}

Ki M. Mujiono di Pura Pakualaman berperan sebagai abdi dalem yang lebih dikenal dengan nama ML. Lebda Bremara. Ia adalah salah satu murid kepercayaan Ki Tjokrowasito, bahkan ketika Tjokrowasito meletakkan jabatannya sebagai pimpinan Uyon-uyon Muryararas di Pura Pakualaman, maka Lebda Bremara lah yang ditunjuk untuk menggantikannya. Kiranya hal tersebut terjadi pada tahun 1976 ketika Tjokrowasito diminta untuk mengajar karawitan di Amerika Serikat, pimpinan Uyon-uyon Manasuka yang 


\begin{tabular}{|c|c|c|c|c|c|}
\hline No. & Hari & Waktu & Jenis Kegiatan & Materi & $\begin{array}{l}\text { Jenis } \\
\text { Siaran }\end{array}$ \\
\hline 1. & Senin & $21.30-00.30$ & Uyon-uyon Manasuka & Gending Klasik & Langsung \\
\hline 2. & Selasa & $12,00-13,30$ & Uyon-uyon Siang & $\begin{array}{l}\text { Gending- } \\
\text { gending } \\
\text { berkarakter } \\
\text { riang }\end{array}$ & Langsung \\
\hline 3. & Selasa & $22.00-00.00$ & Karawitan Iringan & $\begin{array}{l}\text { Pembacaan } \\
\text { Buku }\end{array}$ & Langsung \\
\hline 4. & Rabu & $06.00-07.00$ & Uyon-uyon Pagi & Gending Klasik & Ulang \\
\hline 5. & Rabu & $21.30-00.30$ & Karawitan Iringan & $\begin{array}{l}\text { lringan } \\
\text { Ketoprak }\end{array}$ & Langsung \\
\hline 6. & Kamis & $12.00-13.30$ & Uyon-uyon Siang & $\begin{array}{l}\text { Gending- } \\
\text { gending } \\
\text { Dolanan }\end{array}$ & Langsung \\
\hline 7. & $\begin{array}{l}\text { Kamis } \\
\text { Minggu I }\end{array}$ & $21.30-00.00$ & Uyon-uyon Gadhon & $\begin{array}{l}\text { Iringan } \\
\text { Macapat }\end{array}$ & Langsung \\
\hline 8. & $\begin{array}{l}\text { Kamis } \\
\text { Minggu II }\end{array}$ & $21.30-00.00$ & Karawitan lringan & $\begin{array}{l}\text { Dhanyang } \\
\text { Mataram }\end{array}$ & Langsung \\
\hline 9. & $\begin{array}{l}\text { Kamis } \\
\text { Minggu } \\
\text { III }\end{array}$ & $21.30-00.00$ & Uyon-uyon Nyamleng & Gending Klasik & Rekaman \\
\hline 10 & $\begin{array}{l}\text { Kamis } \\
\text { Minggu } \\
\text { IV }\end{array}$ & $21.30-00.00$ & Uyon-uyon Nyamleng & Santiswaran & Rekaman \\
\hline 11 & $\begin{array}{l}\text { Sabtu } \\
\text { Minggu } \\
\text { terakhir }\end{array}$ & $06.00-07.00$ & $\begin{array}{l}\text { Uyon-uyon Pagi } \\
\text { (Khusus) }\end{array}$ & $\begin{array}{l}\text { Gending- } \\
\text { gending Garap } \\
\text { Soran }\end{array}$ & Rekaman \\
\hline
\end{tabular}

Tabel 1. Jenis kegiatan uyon-uyon di RRI Yogyakarta

dijabat sejak tahun 1951 itu diserahkan kepada Mujiono.

Pada masa kepemimpinannya tidak banyak perubahan-perubahan signifikan yang dilakukan, karena fondasi dan bentuk Uyon-uyon Manasuka telah mencapai posisi mapan. Untuk memberikan porsi siaran terhadap acara lain, sebagian siaran karawitan antara lain gending-gending dalam bentuk soran, dolanan, dan gagrag enggal ditiadakan. Satu hal yang patut dicatat, bahwa Mujiono mencoba menyatukan dua visi karawitan (gaya Surakarta dan Yogyakarta) yang saat itu menjadi bahan perbincangan. Penyatuan dua visi tersebut diaplikasikan dalam bentuk uyon-uyon talu. Talu adalah rangkaian bentuk uyon-uyon yang dilakukan sebelum pertunjukan wayang kulit purwa dimulai. Gending-gending yang terpaket dalam talu itu, baik dalam gaya Surakarta maupun Yogyakarta disebut gending patalon. Adapun pemakaian gending patalon untuk gaya Yogyakarta dan Surakarta berbeda.
Gending-gending untuk Uyon-uyon talu gaya Yogyakarta meliputi gending Lambangsari dhawah ladrang Lipursari kalajengaken Ayakayak terus Srepegan dan diakhiri Sampak, dibawakan dalam Laras Slendro Patet Manyura. Adapun untuk gaya Surakarta meliputi gending Cucurbawuk dhawah Pareanom kalajengaken Ladrang Sri Katon kasambet Ketawang Suksma Ilang terus Ayak-ayak, Srepeg, diakhiri dengan Sampak, dibawakan dalam Laras Slendro Patet Manyura. Apabila Pura Pakualaman mengadakan pergelaran wayang purwa, maka gending patalon dibawakan dalam gaya Yogyakarta. Sebaliknya apabila keraton mengadakan pergelaran serupa, maka penggunaan gending patalon dibawakan dalam gaya Surakarta. Apapun materi yang disajikan, Uyon-uyon Manasuka tetap saja mendapatkan tempat tersendiri di hati masyarakat karena secara psikologis telah menyatu dengan para pandhemennya. 


\section{Periode Ki Suhardi (1985-1994)}

Sama halnya dengan Ki Mujiono, Ki Suhardi merupakan salah satu abdi dalem Pura Pakualaman dan juga murid Ki Tjokrowasito, hanya saja lebih yunior apabila dibandingkan dengan Ki Mujiono. Dalam hal garapgending, ia benar-benar menguasai dasar-dasar pokok baik gaya Surakarta maupun Yogyakarta. Hal itu adalah tidak mengherankan karena sejak kecil telah aktif berkecimpung di dunia karawitan. Dengan ditopang seperangkat gamelan perunggu laras slendro dan pelog, ia selalu aktif mengadakan latihan-latihan bersama kelompoknya di rumah kediamannya kawasan Gedong Kuning, Banguntapan, Bantul. Adapun para pendukungnya sebagian besar adalah abdi dalem Pura, karyawan RRI Yogyakarta, dan sebagian lainnya adalah mahasiswa asing yang mendapat tugas belajar mendalami seni karawitan Jawa.

Setiap akan menyelenggarakan siaran Uyonuyon Manasuka ia selalu mempersiapkan dengan matang materi yang akan disajikan. Materi tersebut dituangkan dalam bentuk notasi, meliputi notasi balungan, vokal, cakepan dan sindhenan, lengkap dengan titilarasnya. Maksud dan tujuan penggunaan notasi itu di samping untuk memperkecil kesalahan sewaktu pergelaran berlangsung, juga dapat dipakai sebagai bahan dokumen untuk dapat dipergunakan sewaktuwaktu dalam keperluan-keperluan lain. Tentang garap karawitan, Suhardi menekankan dalam gaya Surakarta dengan pola sajian yang jelas, tegas, dan nyata. Apabila berkeinginan menampilkan penyajian dengan pola gaya Yogyakarta, maka dilakukan hal yang sama. Penyajian karawitan dengan gaya Yogyakarta biasanya hanya dilakukan saat-saat tertentu saja, dan biasanya hanya dalam porsi sedikit. Untuk memberikan suasana lain, Suhardi mencoba menampilkan gending-gending dalam garap bedhayan, yaitu jenis komposisi gending yang lazim dipergunakan untuk mengiringi tarian bedhaya dan memiliki struktur penyajian yang spesifik (Siswadi, 1994: 6).

\section{Periode Ki Sugiarto (1994-2002)}

Tidak banyak inovasi yang dilakukan oleh $\mathrm{Ki}$ Sugiarto, karena kondisi Uyon-uyon Manasuka telah ada pada posisi mapan sebagaimana periode sebelumnya, sehingga tinggal menjaga kelangsungannya. Satu hal yang dilakukan oleh Sugiarto, bahwa penata gending pada setiap penyelengaraan Uyon-uyon Manasuka selalu berganti-ganti. Hal ini dilakukan agar masing-masing personil pendukung dapat berperan aktif dan diberi kesempatan mengembangkan bakat serta kemampuannya untuk kemudian disumbangkan dalam rangka memajukan siaran Uyon-uyon Manasuka. Di luar konteks Uyon-uyon Manasuka, Sugiarto mencoba menghidupkan kesenian Laras Madya, sebuah tradisi lama yang keberadaannya hampir punah.

Laras madya adalah jenis kesenian berlatar belakang Islami yang pada awalnya hidup dan berkembang di desa-desa khususnya di lingkungan wilayah DIY dan sekitarnya. Bentuknya sangat sederhana, yaitu terdiri dari koor vokal pria dengan diiringi sejumlah instrumen terbang (rebana), di kalangan masyarakat lebih dikenal dengan seni terbangan. Syair-syair yang dilantunkan dalam seni terbangan ini diambil dari tembang macapat. Seni terbangan yang sama tetapi syairsyairnya mengambil dari Serat Centhini disebut Santiswaran. Ada jenis seni terbangan lain, yang pada penyajiannya bersifat insidental, yakni slawatan Slaka dan slawatan Mulud. Slawatan Slaka secara formal hanya dipergelarkan sekali dalam setahun pada bulan Desember oleh umat Kristiani untuk memperingati kelahiran Yesus Kristus, sedang Slawatan Mulud secara formal dipergelarkan pada bulan Jawa Mulud, yakni untuk memperingati kelahiran Nabi Muhammad SAW.

Oleh karena jumlah pendukung karawitan di RRI Yogyakarta pada saat ini sangat terbatas, maka untuk menopang terselenggaranya siaran Laras Madya perlu dukungan dari perkumpulan yang ada di luar RRI., dan ternyata langkah tersebut dapat terselenggara dengan baik.

\section{Periode Ki Murwanto (2002-sekarang)}

Kehidupan kesenimanan Ki Murwanto tidak dapat lepas dari Ki Mujiono dan Ki Suhardi, karena di samping Murwanto adalah muridnya juga sama-sama sebagai abdi dalem Pura dan karyawan RRI Yogyakarta. Dengan demikian apa yang dicanangkan oleh Murwanto tidak jauh berbeda dengan langkah yang dilakukan oleh Mujiono dan Suhardi. Menurut Murwanto, karawitan dalam gaya Surakarta dan Yogyakarta apabila digarap dengan cara yang benar serta ditunjang kemampuan cukup, keduanya akan 
terasa enak untuk dinikmati. Lebih lanjut Murwanto mengatakan bahwa dasar-dasar untuk menggarap sebuah gending (baik gaya Yogyakarta maupun Surakarta) pada hakekatnya adalah sama, perbedaannya terletak pada teknik dan pola (wawancara Ki Murwanto). Gending-gending yang disiarkan RRI Yogyakarta pada hari Senin tanggal 24 Maret 2003 adalah hasil aransmen Murwanto, meliputi: (1). Damar Keli, gending ketuk 4 kerep minggah 8 kalajengaken Ladrang Kanda Manyura laras slendro patet manyura. (2). Bontit, gending ketuk 4 kerep minggah 8 kalajengaken Ladrang Wani-wani Semarangan laras pelog patet nem. (3). Rara Wudu, gending ketuk 2 kerep minggah 4 laras slendro patet sanga.

\section{Uyon-uyon Siang}

RM. Soedarsono (1987/1988) dalam penelitiannya tentang karawitan ibu-ibu di DIY. tercatat ada sejumlah 468 grup yang tersebar di empat kabupaten dan satu kotamadya. Walaupun dari jumlah itu tidak seluruhnya aktif dalam melakukan kegiatan, namun hasil penelitian Soedarsono yang bersifat kuantitatif itu telah cukup untuk memberikan gambaran bahwa dalam kurun waktu 1970-1988 banyak sekali karawitan ibu-ibu yang mewarnai kehidupan masyarakat DIY. Tentang gaya yang disajikan baik melalui RRI Yogyakarta maupun TVRI (Televisi Republik Indonesia) Stasiun Yogyakarta, Soedarsono tidak menguraikan secara spesifik.

Pada tahun 1985-an RRI Yogyakarta mencoba menjaring grup-grup karawitan yang juga terdapat di DIY. untuk keperluan membantu penyelenggaraan uyon-uyon siang. Sebanyak 60 grup yang mendaftar setelah diadakan seleksi hasilnya: 56 grup lolos dan memenuhi kriteria untuk dapat disiarkan melalui RRI Yogyakarta dan 4 grup dinyatakan gugur. Dari jumlah 56 grup itu, 40 grup di antaranya telah dalam keadaan mapan, sedang lainnya masih harus mendapatkan bimbingan. Dari keseluruhan grup yang mendaftar, tidak lebih 10 grup berlatar belakang gaya Yogyakarta, sedang lainnya berlatar belakang gaya Surakarta. Selanjutnya grup karawitan yang lolos seleksi tersebut diberi kesempatan untuk mengadakan siaran di RRI Yogyakarta secara berurutan sesuai dengan jadwalnya. Sebanyak tiga kali dalam seminggu uyon-uyon siang mengudara pada hari-hari Selasa, Kamis, dan Sabtu pukul
12.00 hingga 13.00. Rata-rata 2-3 bulan sekali masing-masing grup mendapat kesempatan untuk siaran. Pada hari Kamis tanggal 12 Desember 2002, tampil siaran grup karawitan Mlathi Rinonce di bawah asuhan Suroto dari Sendangdadi, Mlati, Sleman. Materi yang disajikan meliputi Gending Erang-erang Bagelen ketuk 2 kerep dhawah Opak Apem kalajengaken Jineman Marikangen, laras pelog patet lima dan Bawa Sekar Tengahan Kuswaraga katampen Gending Kutut Manggung ketuk 2 kerep dhawah lancaran Krida Nganglang laras slendro patet manyura. Dua hari kemudian, Sabtu tanggal 14 Desember 2002 grup karawitan Mudha Wirama tampil dengan 2 gending, masingmasing Gending Lagu Dempel minggah Ladrang Cluntang laras slendro patet sanga dan Gending Tejaningsih ketuk 2 kerep kalajengaken Playon Bedhayan laras pelog patet lima. Baik Mlathi Rinonce maupun Mudha Wirama membawakan materinya dalam gaya Surakarta. Bahkan Institut Seni Indonesia Yogyakarta yang secara geografis ada dalam wilayah Yogyakarta dan memiliki Jurusan Seni Karawitan sejak masih dalam tingkat akreditasi akademi (Akademi Seni Tari Indonesia [ASTI], 1980/1981), sangat sedikit menyajikan materi dengan gaya Yogyakarta pada siaran di RRI Yogyakarta. Walaupun penyelenggaraan siaran atas nama lembaga ISI Yogyakarta, namun sebagai pelaksananya adalah Jurusan Seni Karawitan yang didominasi oleh para dosen, selebihnya adalah mahasiswa dari jurusan yang sama. Sebagian besar materi siaran dibawakan dalam gaya Surakarta. Dari dua gending yang disajikan (apabila berdurasi panjang), satu gending disajikan dalam gaya Yogyakarta, sedang lainnya disajikan dalam gaya Surakarta atau bahkan kedua-duanya gaya Surakarta.

Sepanjang penyelenggaraan siaran karawitan di RRI Yogyakarta, sebagai penata gending dipercayakan kepada para dosen Jurusan Seni Karawitan. Seperti siaran yang dilakukan pada hari Kamis tanggal 21 November 2002 pukul 12.10 hingga 13.00, semua materi yang ditata oleh Sutrisni itu dibawakan dalam gaya Surakarta. Adapun materi tersebut adalah Gending Tejosari dhawah Sembawa lampah bedhayan laras pelog patet lima; Suluk Jingking terus Ayak-ayak Jingking mawi uran-uran Maskumambang-Durma laras pelog patet lima; Gending Sendang Arum dhawah Ladrang Nginum laras slendro patet manyura. Sebanyak 22 dosen di Jurusan Seni Karawitan, 
memiliki kompetensi karawitan gaya Surakarta dan Yogyakarta yang berimbang, sehingga untuk menggarap penyajian karawitan baik gaya Yogyakarta maupun Surakarta sebenarnya tidak ada problem. Akan tetapi fenomena yang terjadi di RRI Yogyakarta menunjukkan bahwa gaya Surakarta hampir mendominasi dalam siaransiarannya.

Pada tahapan selanjutnya siaran uyon-uyon siang RRI Yogyakarta banyak diwarnai garapan-garapan karawitan gaya Yogyakarta. Ada kemungkinan bahwa hal tersebut disebabkan (salah satunya) karena pengaruh atas terbentuknya Komunitas Karawitan Bantul (KKB). KKB sendiri terbentuk atas kepedulian masyarakat seni (khususnya seni karawitan) di Bantul yang diprakarsai oleh Trustho pada tahun 2007. Adapun tujuan didirikan $\mathrm{KKB}$ adalah untuk wadah kegiatan berkarawitan dan sudah barang tentu sebagai upaya untuk ikut melestarikan karawitan gaya Yogyakarta. Dengan demikian banyak bermunculan grup-grup karawitan yang mengacu pada garap karawitan gaya Yogyakarta. Dalam kiprahnya, KKB melalui pengurusnya telah menyelenggarakan berbagai kegiatan, di antaranya adalah lomba karawitan gaya Yogyakarta antar kecamatan se-kabupaten Bantul. Kegiatan lomba karawitan tersebut mendapatkan sambutan positif dari masyarakat, khususnya komunitas karawitan Jawa. Hingga kini kegiatan tersebut telah berlangsung tiga kali dan berjalan dengan baik. Di samping itu, Pemerintah Provinsi Daerah Istimewa Yogyakarta juga menyelenggarakan agenda rutin lomba karawitan ibu-ibu antar kabupaten-kota madya sekali dalam setahun yang materinya juga gaya Yogyakarta. Secara psikologis adanya kegiatan-kegiatan tersebut sangat berpengaruh dalam mendorong dan melestarikan kelangsungan karawitan gaya Yogyakarta. Bagi RRI Yogyakarta, penggunaan gaya pada materi dalam siarannya tidak menjadikan masalah, hal ini justru merupakan menu yang variatif untuk memberikan hiburan kepada masyarakat.

\section{Penutup}

Perjalanan sejarah yang sarat dengan segala macam peristiwa memang patut dicatat dan dihargai untukdijadikan bahan referensi. Demikian pula yang dialami oleh RRI Yogyakarta, liku-liku dan perjuangannya telah mampu memberikan kontribusi tidak hanya dalam wilayahnya, akan tetapi juga dalam wilayah budaya khususnya karawitan Jawa yang dipandang penting untuk didokumentasikan. Uyon-uyon Manasuka merupakan salah satu produk RRI Yogyakarta yang kemudian namanya menjadi terkenal dengan sebutan lengkap Uyon-uyon Manasuka RRI Yogyakarta. Pembentukan dan perkembangannya yang membutuhkan proses waktu cukup panjang itu sudah selayaknya mendapatkan legitimasi penuh dari masyarakat khususnya komunitas karawitan dan pendukungnya. Masalah materi yang disajikan tidak mengacu secara penuh pada salah satu gaya justru memberikan warna khas pada Uyon-uyon Manasuka RRI Yogyakarta. Bahkan Uyon-uyon Manasuka merupakan salah satu dari tiga pusat garap yang mewarnai kehidupan karawitan di Yogyakarta, yaitu Keraton Yogyakarta, Pura Pakualaman, dan Uyon-uyon Manasuka RRI Yogyakarta sendiri.

Apapun materi yang disajikan oleh Uyon-uyon Manasuka RRI Yogyakarta tetap saja legitimate, masyarakat tidak akan mempermasalahkannya karena yang dibutuhkan adalah sebuah hiburan. Ketenaran Uyon-uyon Manasuka RRI Yogyakarta telah terjadi sejak awal tengah kedua abad ke-20 (tahun 1960-an), hingga dewasa ini kiprahnya menjadi kian meluas yakni dengan adanya keterlibatan masyarakat melalui kontak interaktif. Fenomena ini telah menunjukkan cukup bukti bahwa antara Uyon-uyon Manasuka dan RRI Yogyakarta telah menjadi satu kesatuan yang tidak dapat dipisahkan serta menjadi salah satu bentuk representasi budaya bagi masyarakat Yogyakarta khususnya di bidang karawitan.

\section{Kepustakaan}

Kriswanto. 2008. Dominasi Karawitan Gaya Surakarta di Daerah Istimewa Yogyakarta. Surakarta: ISI Press,.

Mantra, Ida Bagus. 1985. "Beberapa Masalah Kependudukan di Indonesia" dalam Suryo Sumarno, dkk. RRI Nusantara II Yogyakarta: Bergulat Dalam Karya. Yogyakarta: PT BP Kedaulatan Rakyat

Paku Alam VIII. 1985. "Sambutan Wakil Gubernur Daerah Istimewa Yogyakarta pada peringatan Ulang Tahun ke 40 RRI Yogyakarta dalam Suryo Sumarno, dkk. RRI Nusantara II Yogyakarta: Bergulat Dalam Karya. Yogyakarta: PT BP Kedaulatan Rakyat. 
Rais, Amin. 1985. "RRI dan Kehidupan Beragama” dalam Suryo Sumarno, dkk. RRI Nusantara II Yogyakarta: Bergulat Dalam Karya. Yogyakarta: PT BP Kedaulatan Rakyat,.

Siswadi. 1994. "Gending Bedayan Yogyakarta: Satu kajian terhadap kalimat lagu vokal". Laporan Penelitian. Yogyakarta: Lembaga Penelitian Institut Seni Indonesia Yogyakarta

Sumarno, Suryo, dkk. 1985. RRI Nusantara II: Bergulat dalam Karya. Yogyakarta: PT BP Kedaulatan Rakyat.

\section{Informan:}

R. Wiranto. 70 tahun. Seniman karawitan.

Ki Murwanto. 56 tahun. Seniman karawitan dan ketua karawitan RRI Yogyakarta

Ki Sugiarto. 70 tahun. Tokoh karawitan dan mantan ketua karawitan RRI Yogyakarta

Trustho. 47 tahun. Seniman dan akademisi karawitan. 